\title{
Sistem Pakar Syarat Tumbuh Optimal Tanaman Industri Menggunakan Javascript dan Html
}

\author{
System Expert of Optimizing Growth Requirements for Industrial Plants Using \\ Javascript and Html
}

\author{
Aneke Rintiasti \\ Baristand Industri Surabaya \\ Kementerian Perindustrian \\ Surabaya, Indonesia \\ anekerintiasti@gmail.com
}

\author{
Ikhwan Krisnadi \\ PTPN X \\ Surabaya, Indonesia
}

\author{
Aan Anto Suhartono \\ Baristand Industri Surabaya \\ Kementerian Perindustrian \\ Surabaya, Indonesia
}

\begin{abstract}
Abstrak-- Ekspor produk non migas Indonesia salah satunya berasal dari industry perkebunan. Industri perkebunan tentunya tidak dapat dipisahkan dengan pengolahan lahan perkebunan. Basis pengetahuan berupa informasi syarat tumbuh tanaman industri, yang didapatkan melalui penelitian sebelumnya dilakukan uji coba lapangan. Penelitian bertujuan untuk mengembangan system pakar yang dapat mengetahui tingkat kecocokan karakteristik tanah untuk beberapa tanaman industri dengan menggunakan javascript dan Html. Tanaman Industri yang digunakan dalam penelitian ini terdiri dari Cengkeh, Kopi Robusta, Kopi Arabika, Tebu, Coklat dan Teh. Metode sistem pakar dengan menggunakan 5 (lima) parameter kunci yaitu : intensitas penyinaran, $\mathrm{pH}$ tanah, jenis tanah, curah hujan, bulan kering. Pada uji coba lapangan digunakan beberapa sensor antara lain : Sensor Suhu, Sensor Kelembapan, Sensor pH. Aplikasi Sistem Pakar telah berhasil disusun dalam aplikasi berbasis website dan menggunakan rule sesuai pohon keputusan.
\end{abstract}

Kata Kunci-- Sistem Pakar, Syarat Tumbuh Optimal, Lahan Tanaman Industri

\begin{abstract}
One of Indonesia's non-oil and gas product exports comes from the plantation industry. The plantation industry is certainly inseparable from processing plantation land. Knowledge base in the form of information on the requirements for growing industrial plants, which was obtained through previous research conducted field trials. The research aims to develop an expert system that can determine the compatibility level of soil characteristics for several industrial plants using javascript and Html. Industrial plants used in this study consisted of Cloves, Robusta Coffee, Arabica Coffee, Sugar Cane, Chocolate and Tea. Expert system method using 5 (five) key parameters, namely: irradiation intensity, soil $\mathrm{pH}$, soil type, rainfall, dry month. In the field trials several sensors were used, among others: Temperature Sensor, Humidity Sensor, pH Sensor. Expert System applications have been successfully compiled in website-based applications and use rules according to decision trees.
\end{abstract}

Keywords-- Expert System, Optimal Growing Requirements, Industrial Plant Land

\section{PENDAHULUAN}

Lidah buaya merupakan salah satu tanaman yang memiliki beberapa keuntungan, diantaranya adalah sebagai bahan yang berguna untuk regenerasi sel kulit, antioksidan, adstringen dan antiseptic ${ }^{[1]}$. Keistimewaan lidah buaya ini terletak pada gelnya yang dapat membuat kulit tidak cepat kering dan selalu kelihatan lembab. Keadaan tersebut disebabkan sifat gel lidah buaya yang mampu meresap ke dalam kulit, sehingga dapat menahan kehilangan cairan yang terlampau banyak dari dalam kulit. Kandungan saponin yang terdapat dalam gel lidah buaya dapat membersihkan kotoran dari kulit, melembutkan, melembabkan dan menambah kehalusan kulit ${ }^{[2]}$. Kekayaan akan kandungan bahan yang didapat berfungsi sebagai bahan kosmetik, obat dan pelengkap gizi menjadikan lidah buaya sebagai tanaman ajaib, karena tidak ada lagi tanaman lain yang mengandung bahan yang menguntungkan bagi kesehatan selengkap yang dimiliki tanaman tersebut.

Nilai ekspor non migas tahun 2015 mengalami penurunan sebesar 9,77 persen dibandingkan tahun 2014 yang mencapai USD 145,96 Miliar [1]. Nilai ekspor produk non migas salah satunya berasal dari industri perkebunan. Industri perkebunan tentunya tidak dapat dipisahkan dengan pengolahan lahan perkebunan. Pada era yang serba modern ini, banyak digunakan berbagai sistem dalam bentuk aplikasi yang bertujuan untuk memudahkan suatu proses klasifikasi atau untuk memudahkan mendapatkan solusi dari suatu permasalahan. Perubahan dalam bidang teknologi informasi dan pengetahuan, antara lain dengan menggunakan Sistem Pakar.

Penelitian ini bertujuan untuk mengembangkan system pakar yang dapat mengetahui tingkat kesesuaian karakteristik tanah untuk beberapa tanaman industri dengan menggunakan javascript dan Html.

Penelitian sebelumnya [10] menyajikan konsep sistem pakar probabilistik menggunakan jaringan Bayesian untuk secara efektif mendukung pengambilan keputusan 
manusia dan untuk mempercepat proses penyelesaian masalah. Jaringan Bayesian membentuk basis pengetahuan sehingga penalaran di bawah ketidakpastian adalah mungkin dan efektif. Konsep ini telah divalidasi di pabrik laser industri daya tinggi dan menunjukkan hasil pertama yang sangat menjanjikan. Validasi jangka panjang akan memverifikasi keefektifan sistem pakar.

Makalah ini [11] menyajikan investigasi dalam pengembangan sistem pakar berkemampuan seluler yang cerdas untuk melakukan deteksi otomatis penyakit tuberkulosis (TB) secara real-time. Makalah ini telah menyajikan skema deteksi antibodi spesifik antigen spesifik TB berbasis plasmonik berbasis ponsel menggunakan smartphone dengan integrasi teknik pembelajaran mesin. Deteksi TB berbasis ELISA plasmonik dikembangkan pada platform Android. Aplikasi mobile dikembangkan pada Samsung Galaxy S7 edge. SDK target minimum adalah 21 (API level 5).

Makalah ini [12] menyajikan pengembangan sistem pakar yang dirancang untuk melatih profesional muda untuk menerapkan strategi manajemen mobilitas untuk mempengaruhi perubahan dari pilihan transportasi pasif ke transportasi aktif yaitu bersepeda dan berjalan. menggunakan Visual Basic.NET sebagai alat dan MySQL sebagai alat pendukung. Sistem pakar pada akhirnya akan memberikan saran tentang strategi terbaik yang akan dilaksanakan berdasarkan pemilihan tujuan utama dan tujuan spesifik oleh pengguna.

Pengembangan dua sistem pakar pendidikan di universitas internasional swasta [13]. Sistem pakar pertama adalah sistem penasehat kursus yang merekomendasikan kursus untuk mahasiswa. Sistem kedua menyarankan beasiswa untuk mahasiswa sarjana berdasarkan kelayakan mereka. Meskipun ada sistem yang dilaporkan untuk penasehat kursus, literatur tampaknya tidak mengandung referensi ke sistem pakar untuk rekomendasi beasiswa dan pemeriksaan kelayakan. Oleh karena itu pemberi beasiswa yang kami kembangkan adalah yang pertama dari jenisnya. Kedua sistem telah diimplementasikan dan diuji menggunakan perangkat lunak Oracle Policy Automation (OPA)

Sistem pakar untuk pariwisata di Yordania (ESTJ) [14] dikembangkan untuk merekomendasikan jadwal perjalanan yang cocok yang memuaskan minat wisatawan. Sistem ini berguna bagi wisatawan, dan pariwisata, agen untuk memilih paket terbaik berdasarkan waktu, anggaran, dan preferensi tempat wisata yang diperlukan. Sistem ini dirancang sebagai sistem pakar berbasis aturan dan diimplementasikan dengan bahasa prolog. Sistem dievaluasi dan diuji dengan spesialis dan hasilnya disimpulkan hingga tingkat ahli manusia menggunakan prolog.

Sedangkan system pakar yang dikembangkan [15] mengembangkan sistem pakar untuk tanaman jati menggunakan metode forward chaining.
Membangun sistem pakar yang dapat digunakan untuk menentukan evaluasi lahan tanaman Nilam [16]. Input pemrosesan untuk sistem pakar terdiri atas dua format, yaitu input fuzzy dan input non-fuzzy. Pertama, Fuzzy Inference System(FIS) dengan metode Mamdani digunakan sebagai metode inferensi untuk output fuzzydiikuti dengan aplikasi input non-fuzzy.

Penelitian ini membangun system pakar Syarat Tumbuh Optimal beberapa tanaman industri yaitu Cengkeh, Kopi Robusta, Kopi Arabika, Tebu, Coklat dan Teh yang basis pengetahuan dan mesin inferensi dikembanggkan menggunakan metode C4.5 menggunakan aplikasi WEKA [5] dan basis data dan antar muka pemakai menggunakan javascript dan html.

\section{BAHAN DAN METODE}

Sistem pakar ini dapat mengetahui tingkat kecocokan karakteristik tanah untuk beberapa tanaman industri. Penelitian ini akan membahas mengenai pembuatan sistem pakar karakteristik tanah untuk lahan tanaman industri. Sistem pakar dibuat dengan basis pengetahuan dari suatu pohon keputusan dan bahasa html dan javascript berbasis website.

Sistem pakar mempunyai beberapa keuntungan jika diterapkan, antara lain:

- Memungkinkan orang awam bisa mengerjakan pekerjaan para ahli.

- Bisa melakukan proses secara berulang secara otomatis.

- Menyimpan pengetahuan dan keahlian para pakar.

- Mampu mengambil dan melestarikan keahlian para pakar (terutama yang termasuk keahlian langka).

- Memiliki kemampuan untuk mengakses pengetahuan.

- Memiliki reabilitas.

- Sebagai media pelengkap dalam pelatihan.

- Menghemat waktu dalam pengambilan keputusan

Sistem pakar juga memiliki beberapa kelemahan, antara lain:

- Biaya yang diperlukan untuk membuat dan memeliharanya sangat mahal.

- Sulit dikembangkan. Hal ini tentu saja erat kaitannya dengan ketersediaan pakar di bidangnya.

- Sistem Pakar tidak $100 \%$ bernilai benar.

Menurut Staugaard (1987) suatu sistem pakar disusun oleh tiga modul utama yaitu :

a. Modul Penerimaan Pengetahuan (Knowledge Acquisition Mode)

Sistem berada pada modul ini, pada saat ia menerima pengetahuan dari pakar. Proses mengumpulkan pengetahuan- 
pengetahuan yang akan digunakan untuk pengembangan sistem, dilakukan dengan bantuan knowledge engineer. Peran knowledge engineer adalah sebagai penghubung antara suatu sistem pakar dengan pakarnya.

b. Modul Konsultasi (Consultation Mode)

Pada saat sistem berada pada posisi memberikan jawaban atas permasalahan yang diajukan oleh user, sistem pakar berada dalam modul konsultasi. Pada modul ini, user berinteraksi dengan sistem dengan menjawab pertanyaanpertanyaan yang diajukan oleh sistem.

c. Modul Penjelasan (Explanation Mode)

Modul ini menjelaskan proses pengambilan keputusan oleh system (bagaimana suatu keputusan dapat diperoleh).

\section{STRUKTUR SISTEM PAKAR}

Komponen utama pada struktur sistem pakar menurut Hu et al (1987) meliputi :

a. Basis Pengetahuan (Knowledge Base)

Basis pengetahuan merupakan inti dari suatu sistem pakar, yaitu berupa representasi pengetahuan dari pakar.

b. Mesin Inferensi (Inference Engine)

Mesin inferensi berperan sebagai otak dari sistem pakar. Mesin inferensi berfungsi untuk memandu proses penalaran terhadap suatu kondisi, berdasarkan pada basis pengetahuan yang tersedia. Dalam prosesnya, mesin inferensi menggunakan strategi penalaran dan strategi pengendalian.

c. Basis Data (Data Base)

Basis data terdiri atas semua fakta yang diperlukan, dimana fakta fakta tersebut digunakan untuk memenuhi kondisi dari kaidah-kaidah dalam sistem. Basis data menyimpan semua fakta, baik fakta awal pada saat sistem mulai beroperasi, maupun fakta-fakta yang diperoleh pada saat proses penarikan kesimpulan sedang dilaksanakan.

d. Antarmuka Pemakai (User Interface)

Fasilitas ini digunakan sebagai perantara komunikasi antara pemakai.dengan komputer.

\section{METODOLOGI}

Berdasarkan [2][3][4] metode penelitian dapat dilihat pada Gambar 1. Data karakteristik syarat tumbuh berasal dari Buku Literatur. Data karakteristik tersebut di olah dalam WEKA untuk mengetahui parameter kunci dan Rule Sistem Pakar.

Tanaman Industri yang digunakan dalam Sistem Pakar ini ada 6 (enam) tanaman industri seperti yang tertuang dalam tabel 1.

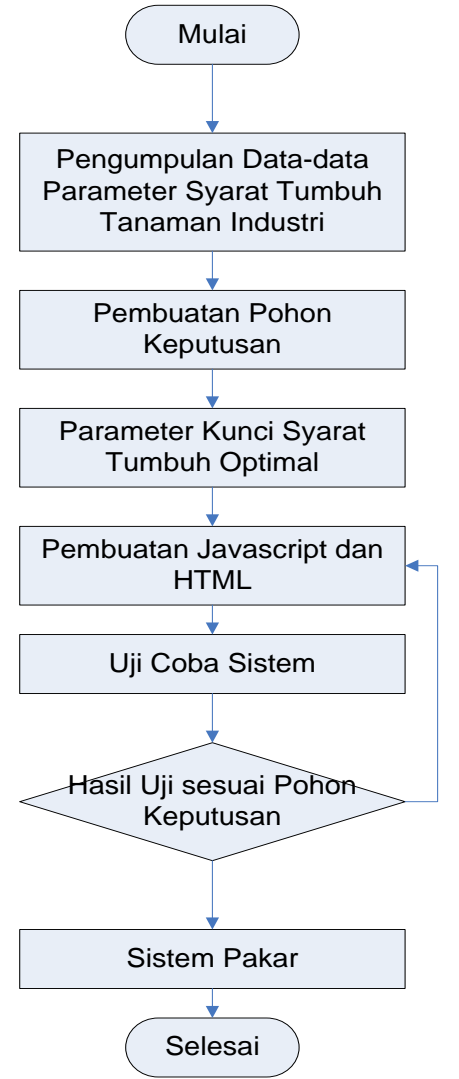

Gambar 1 Metode Penelitian

TABEL 1. TANAMAN INDUSTRI

\begin{tabular}{ccc}
\hline Kode Tanaman & Nama Tanaman & Varietas \\
\hline 1 & Cengkeh & - \\
\hline 2 & Teh & \\
\hline 3 & Kopi & Robusta \\
\hline 4 & Kopi & Arabika \\
\hline 5 & Tebu & \\
\hline 6 & coklat & \\
\hline
\end{tabular}

\section{PEMBUATAN POHON KEPUTUSAN}

Gambar 2 memperlihatkan Pohon keputusan untuk 6 tanaman industry [7][8][9] (Cengkeh, Kopi Robusta, Kopi Arabika, Kakao, Teh dan Tebu) Gambar 0 menyatakan intensitas penyinaran, pH Tanah, Bulan Kering, jenis tanah dan curah hujan sebagai parameter kunci syarat tumbuh optimal [5]. 


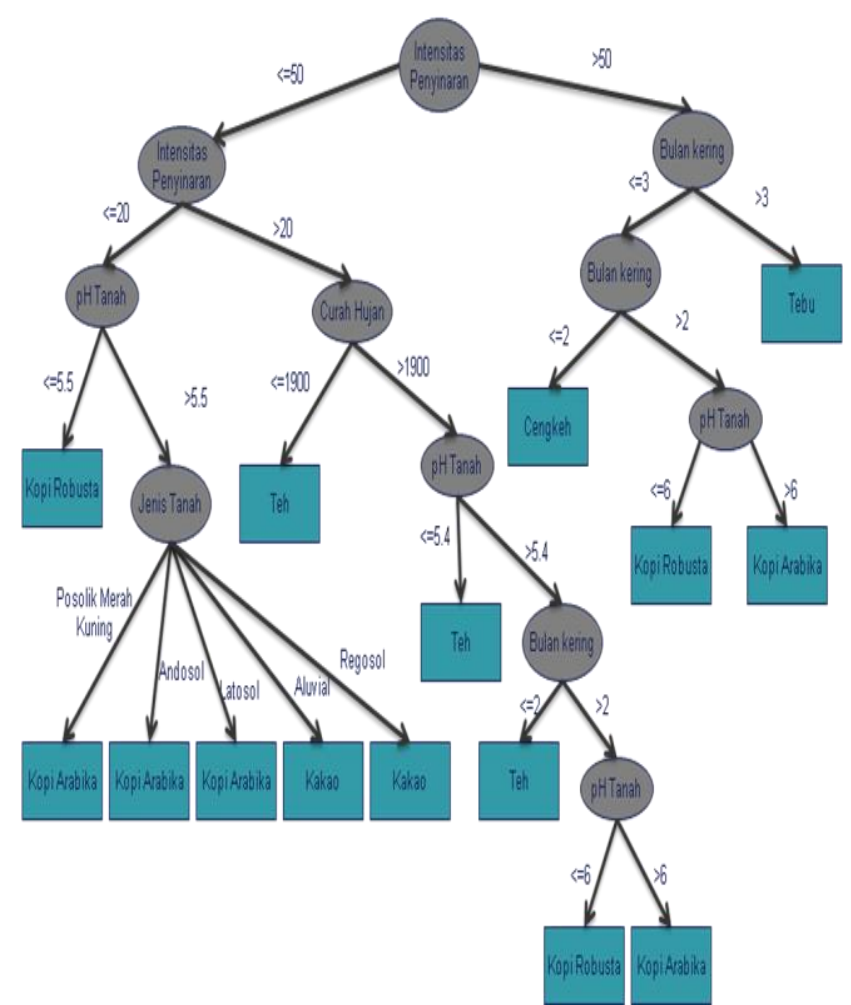

Gambar 2. Pohon keputusan untuk 6 jenis tanaman

Parameter kunci ini juga dapat dirujuk sebagai acuan dalam pembuatan Sistem Pakar [6].

\section{HASIL DAN PEMBAHASAN}

Setelah mendapatkan basis pengetahuan dan mesin inferensi maka langkah selanjutnya adalah menyusun data base dan user interface Gambar 3 .

\subsection{Penyusunan User Interface}

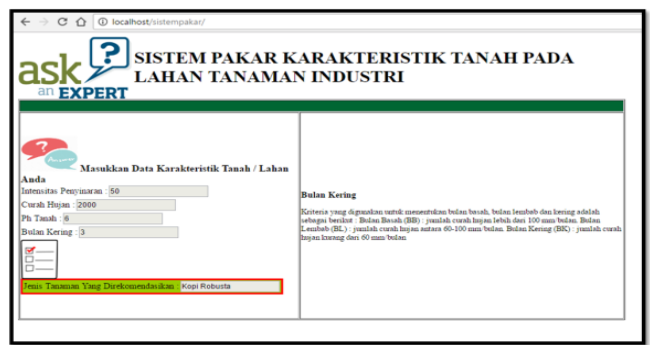

Gambar 3. User Interface Sistem Pakar

Pohon keputusan Gambar 2 telah didapatkan untuk 5 (lima) parameter kunci. Kemudian dilanjutkan dengan membuat Sistem Pakar maka terlebih dahulu mendefinisikan pohon keputusan kedalam bahasa pemrograman javascript, sebagai berikut :

Fungsi pembuatan div yang diberikan default hide atau tidak terlihat, sehingga menyederhanakan user interface pengguna.

\section{$\$($ document).ready(function() \{ $\$(" \#$ divPhTanah").hide(); \$("\#divJenisTanaman").hide(); \$("\#divJenisTanah").hide(); \$("\#divCurahHujan").hide(); \$("\#divBulanKering").hide(); \$("\#divPhTanah2").hide(); \$("\#divPenjelasanCurahHujan").hide(); \$("\#divPenjelasanpHTanah").hide(); \$("\#divPenjelasanBulanKering").hide(); \$("\#divPenjelasanJenisTanah").hide();}

3.1.1 Fungsi tombol 'Selanjutnya' pertama. Ketika pengguna memeasukkan data intensitas penyinaran dan menekan tombol selanjutnya maka rule yang berlaku adalah jika nilai penyinaran < 20 maka ditanya lagi berapa $\mathrm{pH}$ tanahnya.

\section{$\$(" \# b t n N e x t 1 ") . c l i c k(f u n c t i o n()\{$ var SintenPenyinaran = $\$(" \# t x t$ IntensitasPenyinaran").val(); if (\$intenPenyinaran <=20) \\ \{ \$("\#divPhTanah").show(); \$("\#divPenjelasanpHTanah").show(); \$("\#divPenjelasanCurahHujan").hide(); \$("\#divPenjelasanBulanKering").hide(); \$("\#txtIntensitasPenyinaran").prop("readonly", true); $\$($ '\#txtIntensitasPenyinaran').addClass('input- disabled'); \$("\#btnNext1").hide();\}}

3.1.2 Fungsi tombol 'Selanjutnya' pertama. Ketika pengguna memeasukkan data intensitas penyinaran dan menekan tombol selanjutnya maka rule yang berlaku adalah jika nilai penyinaran > 20 dan lebih kecil dari 50 maka ditanya lagi berapa curah hujannya.

$$
\begin{gathered}
\text { else if (\$intenPenyinaran > } 20 \text { \&\& SintenPenyinaran <= 50) } \\
\text { \{\$("\#divCurahHujan").show(); } \\
\text { \$("\#divPenjelasanCurahHujan").show(); } \\
\text { \$("\#divPenjelasanIntensitasPenyinaran").hide(); } \\
\text { \$("\#divPenjelasanpHTanah").hide(); } \\
\text { \$("\#txtIntensitasPenyinaran").prop("readonly", true); } \\
\text { \$('\#txtIntensitasPenyinaran').addClass('input-disabled'); } \\
\text { \$("\#btnNext1").hide(); }
\end{gathered}
$$

Fungsi tombol 'Selanjutnya' pertama. Ketika maka rule yang berlaku adalah jika nilai penyinaran > 50 maka ditanya lagi berapa bulan keringnya. 


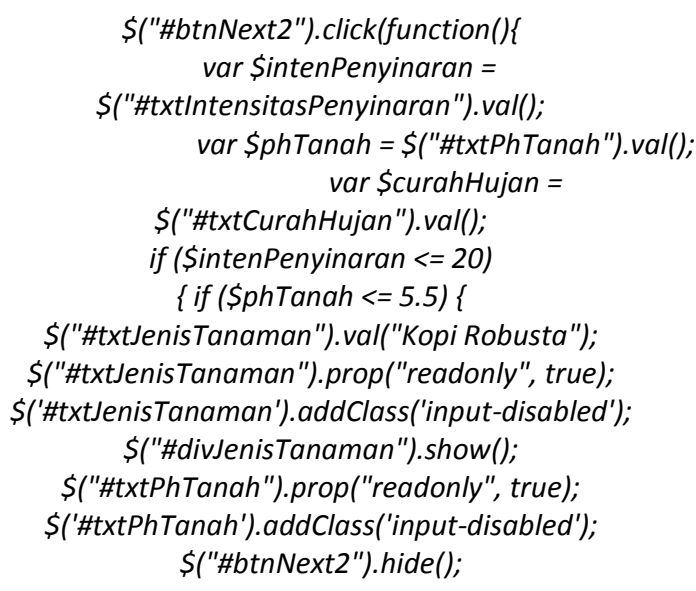

3.1.3 Fungsi tombol 'Selanjutnya' kedua. Ketika pengguna memasukkan data intensitas penyinaran dan menekan tombol selanjutnya maka rule yang berlaku adalah jika nilai penyinaran $<=20$ dan $\mathrm{pH}$ Tanah $<=5.5$ maka jenis tanaman yang cocok adalah Kopi Robusta.

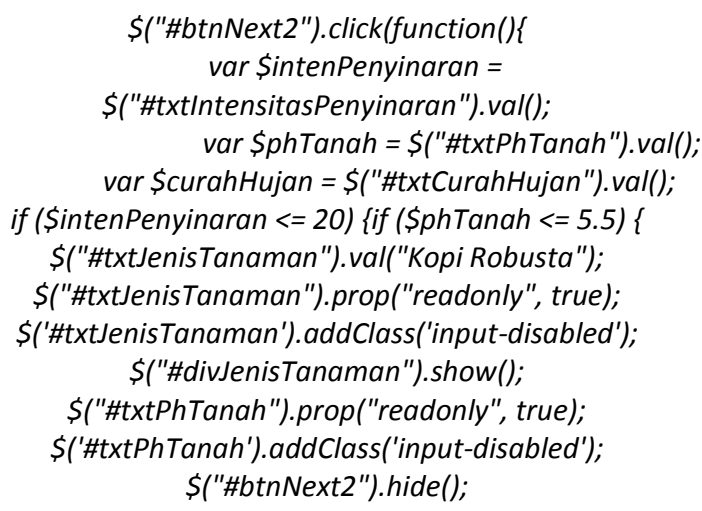

Fungsi tombol 'Selanjutnya' kedua. Ketika pengguna memasukkan data intensitas penyinaran dan menekan tombol selanjutnya maka rule yang berlaku adalah jika nilai penyinaran $<=20$ dan $\mathrm{pH}$ Tanah $<=5.5$ maka jenis tanaman yang cocok adalah Kopi Robusta.

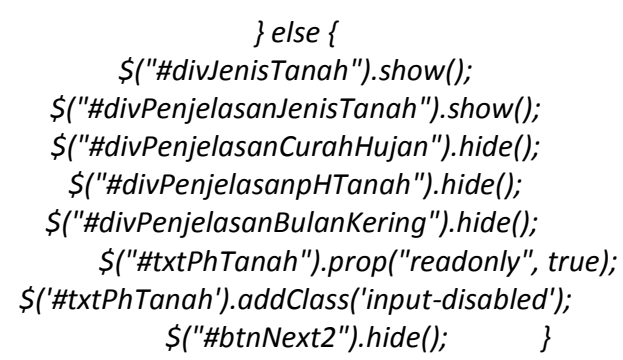

Fungsi tombol 'Selanjutnya' kedua. Ketika pengguna memasukkan data intensitas penyinaran dan menekan tombol selanjutnya maka rule yang berlaku adalah jika nilai penyinaran $<=20$ dan $\mathrm{pH}$ Tanah $>5.5$ ditanya jenis tanah.

Fungsi tombol 'Selanjutnya' kedua. Ketika pengguna memasukkan data intensitas penyinaran dan menekan tombol selanjutnya maka rule yang berlaku adalah jika nilai penyinaran $<=20$ dan curah hujan $>1900$ dan $\mathrm{pH}$ tanah $<=5.4$ maka jenis tanaman adalah teh, namun jika $\mathrm{pH}$ tanah $>5.4$ maka ditanya bulan kering.

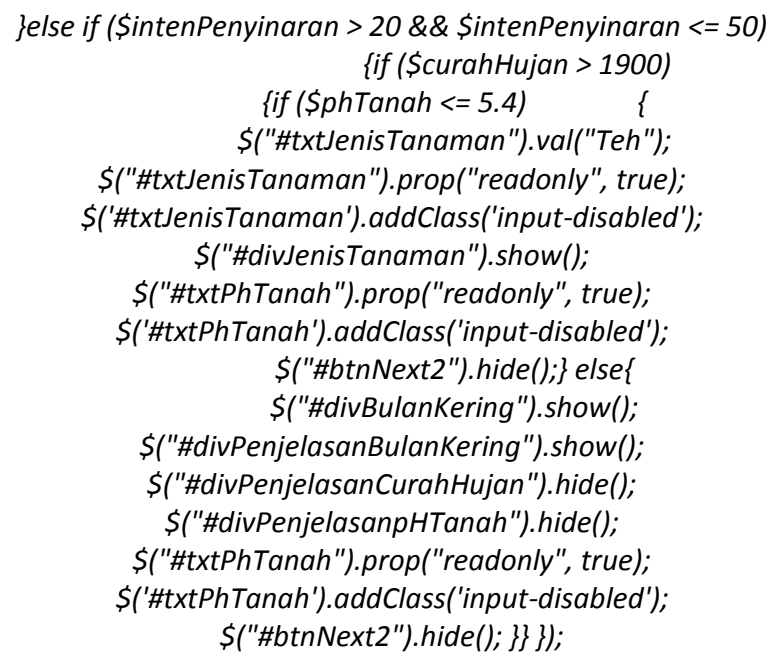

3.1.4 Fungsi tombol 'Selanjutnya' ketiga. Ketika pengguna memasukkan data intensitas penyinaran dan menekan tombol selanjutnya maka rule yang berlaku adalah jika nilai penyinaran $<=20$ dan $\mathrm{pH}$ Tanah $>5.5$ ditanya jenis tanah dan jenis tanah 1 atau jenis tanah 2 atau jenis tanah 3 maka tanaman yang cocok adalah Kopi Arabika, namun jika jenis tanah adalah 4 atau 5 maka tanaman yang cocok adalah kakao.

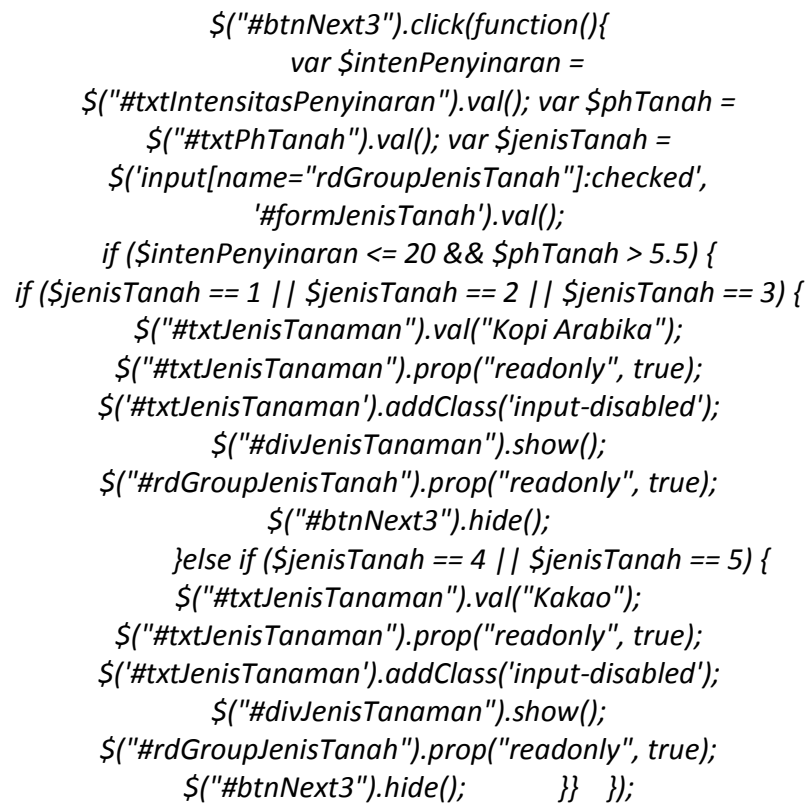

3.1.5 Fungsi tombol 'Selanjutnya' keempat. Ketika pengguna memasukkan data intensitas penyinaran dan menekan tombol selanjutnya maka rule yang berlaku adalah jika nilai penyinaran $>20$ dan $<=50$ dan curah hujan $<=1900$ maka tanaman yang cocok adalah teh dan jika curah hujan $>=50$ maka ditanya $\mathrm{pH}$ tanah. 


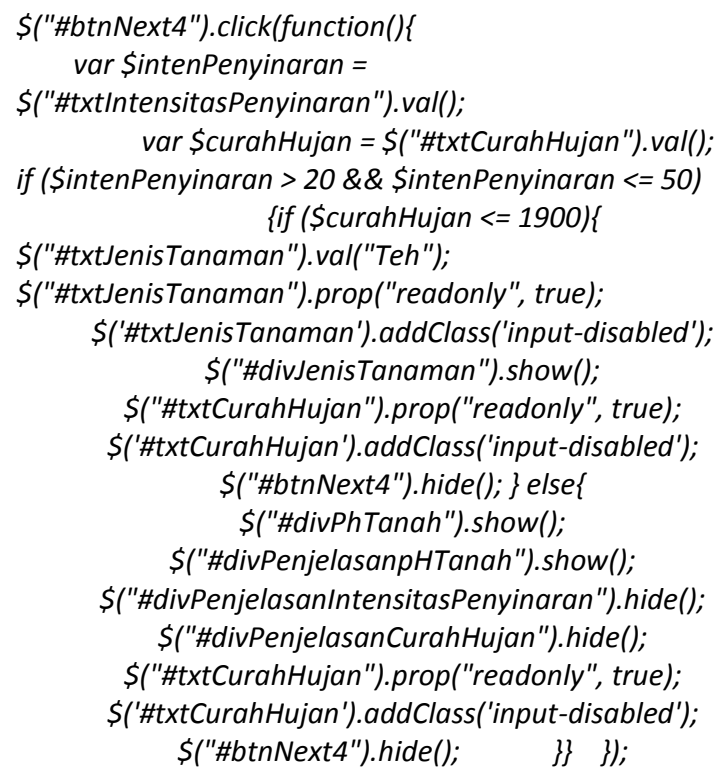

3.1.6 Fungsi tombol 'Selanjutnya' kelima. Ketika pengguna memasukkan data intensitas penyinaran dan menekan tombol selanjutnya maka rule yang berlaku adalah jika nilai penyinaran $>20$ dan intensitas penyinaran $<=50$. Dan jika curah hujan $>1900$ dan ph Tanah $>5.4$ dan bulan kering $<=2$ maka tanaman yang cocok adalah the. Namun jika ph Tanah $<=6$ maka tanaman yang cocok adalah kopi robusta, jika $\mathrm{pH}$ Tanah >6 maka tanaman yang cocok adalah kopi arabika.

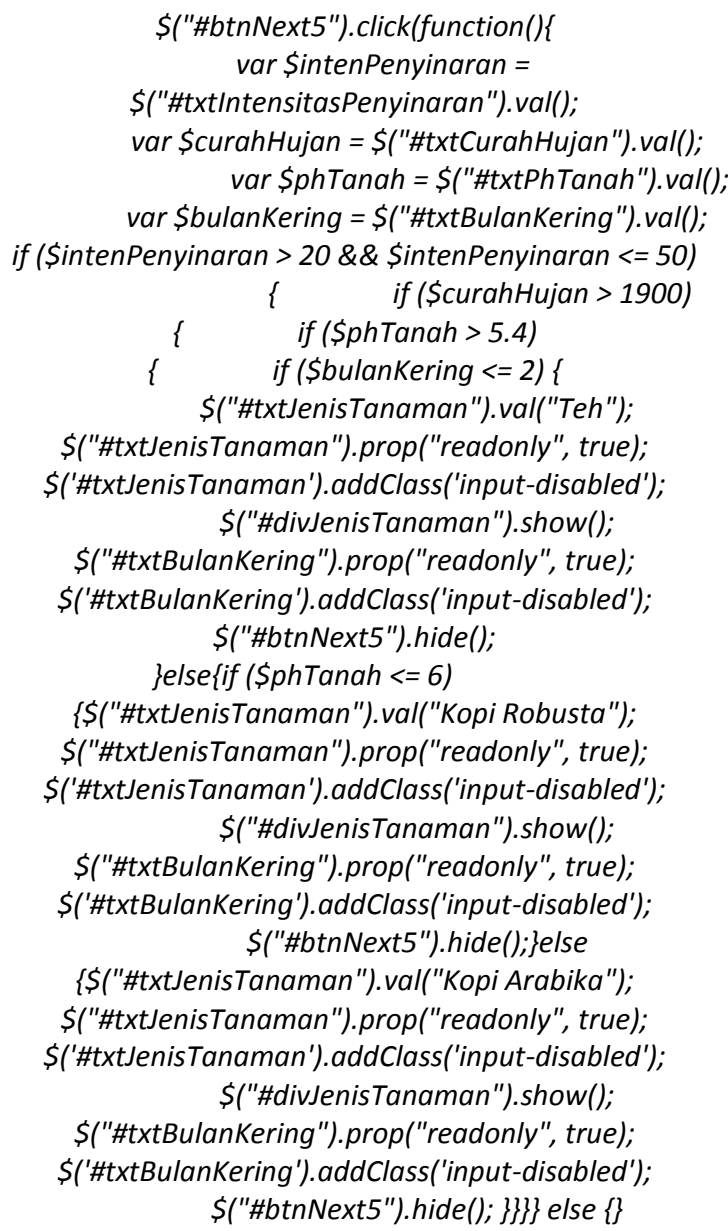

Fungsi tombol 'Selanjutnya' kelima. Ketika pengguna memasukkan data intensitas penyinaran dan menekan tombol selanjutnya maka rule yang berlaku adalah jika nilai penyinaran $>50$ dan bulan kering $>3$ maka tanaman yang cocok adalah tebu. Namun jika bulan kering $<2$ maka tanaman yang cocok adalah cengkeh. Jika bulan kering diantara 2-3 maka ditanya $\mathrm{pH}$ tanahnya. 
\}else if (\$intenPenyinaran $>50)\{$

if (\$bulanKering > 3) \{

\$("\#txtJenisTanaman").val("Tebu");

$\$($ (\#txtJenisTanaman").prop("readonly", true);

$\$($ '\#txtJenisTanaman').addClass('input-disabled'); $\$(" \# d i v J e n i s T a n a m a n ") . s h o w() ;$

\$("\#txtBulanKering").prop("readonly", true);

$\$($ '\#txtBulanKering').addClass('input-disabled'); \$("\#btnNext5").hide();

\}else if (\$bulanKering $<=2)\{$

\$("\#txtJenisTanaman").val("Cengkeh");

\$("\#txtJenisTanaman").prop("readonly", true);

\$('\#txtJenisTanaman').addClass('input-disabled'); $\$(" \# d i v J e n i s T a n a m a n ") . s h o w() ;$

\$("\#txtBulanKering").prop("readonly", true); \$('\#txtBulanKering').addClass('input-disabled'); $\$(" \# b t n N e x t 5 ")$.hide();\}else\{ \$("\#divPhTanah2").show();

\$("\#divPenjelasanpHTanah").show();

\$("\#divPenjelasanCurahHujan").hide();

\$("\#divPenjelasanBulanKering").hide();

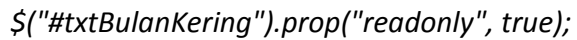

\$('\#txtBulanKering').addClass('input-disabled'); \$("\#btnNext5").hide(); \}\} \});

Fungsi tombol 'Selanjutnya' kelima. Ketika pengguna memasukkan data intensitas penyinaran dan menekan tombol selanjutnya maka rule yang berlaku adalah jika nilai penyinaran $>50$ dan bulan kering diantara 2 s/d 3 dan pH tanah $<=6$ maka tanaman yang cocok adalah kopi robusta. Namun jika pH Tanah >6 maka tanaman yang cocok adalah kopi arabika.

\section{$\$(" \# b t n N e x t 6 ")$. click(function()}

var SintenPenyinaran $=\$(" \#$ txtIntensitasPenyinaran").val(); var \$bulanKering $=\$(" \# t x t$ BulanKering").val();

var \$phTanah = \$("\#txtPhTanah2").val();

if (SintenPenyinaran $>50$ )

if (\$bulanKering $>2$ \& \& \$bulanKering $<=$

3) \{if (\$phTanah $<=6$ )

\$("\#txtJenisTanaman").val("Kopi Robusta");

\$("\#txtJenisTanaman").prop("readonly", true);

\$('\#txtJenisTanaman').addClass('input-disabled'); $\$(" \# d i v J e n i s T a n a m a n ")$.show();

\$("\#txtPhTanah2").prop("readonly", true);

\$('\#txtPhTanah2').addClass('input-disabled'); $\$(" \# b t n N e x t 6 ") . h i d e() ;\} e l s e\{$

\$("\#txtJenisTanaman").val("Kopi Arabika");

\$("\#txtJenisTanaman").prop("readonly", true);

$\$(' \# t x t J e n i s T a n a m a n ') . a d d C l a s s(' i n p u t-d i s a b l e d ') ;$ \$("\#divJenisTanaman").show();

\$("\#txtPhTanah2").prop("readonly", true);

$\$($ '\#txtPhTanah2').addClass('input-disabled'); ("\#btnNext6").hide(); \}\} \} \}); \}); </script>

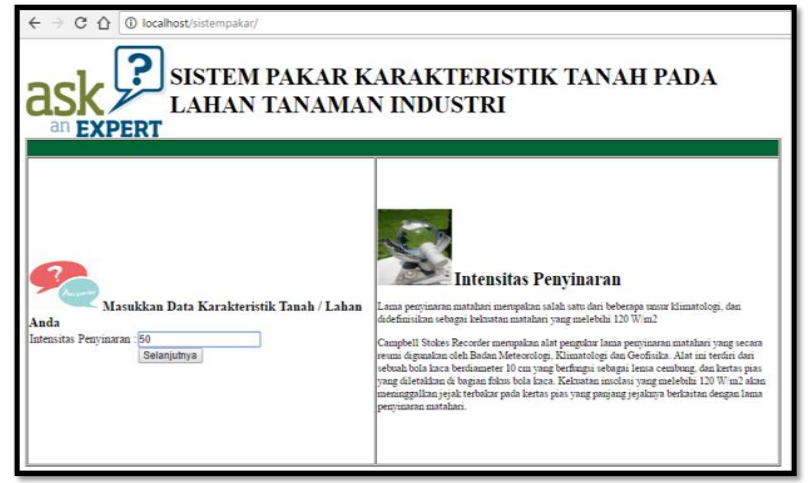

Gambar 4. User Interface Sistem Pakar Data Intensitas Penyinaran

Dari User Interface pada Gambar 4, yang data yang diminta oleh system pakar pertama kali adalah Intensitas Penyinaran. Dari jawaban tersebut muncul pertanyaan surah hujan pada Gambar 5.

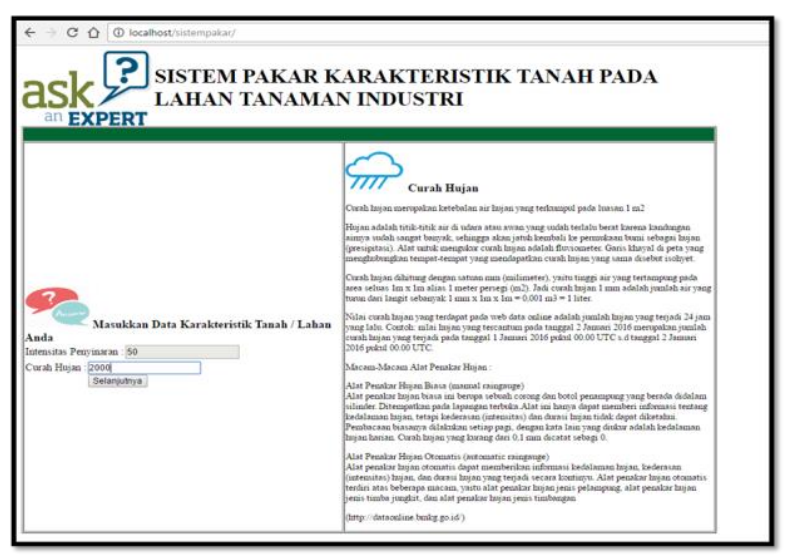

Gambar 5. User Interface Sistem Pakar Data Curah Hujan

Pada Gambar 5, pertanyaan lanjutan adalah $\mathrm{pH}$ tanah. Yang dilanjutkan dengan pertanyaan bulan kering pada Gambar 6. Pada akhirnya terlihat saran untuk tanaman yang paling optimal sesuai dengan karakteristik yang dimasukkan kedalam Sistem Pakar.

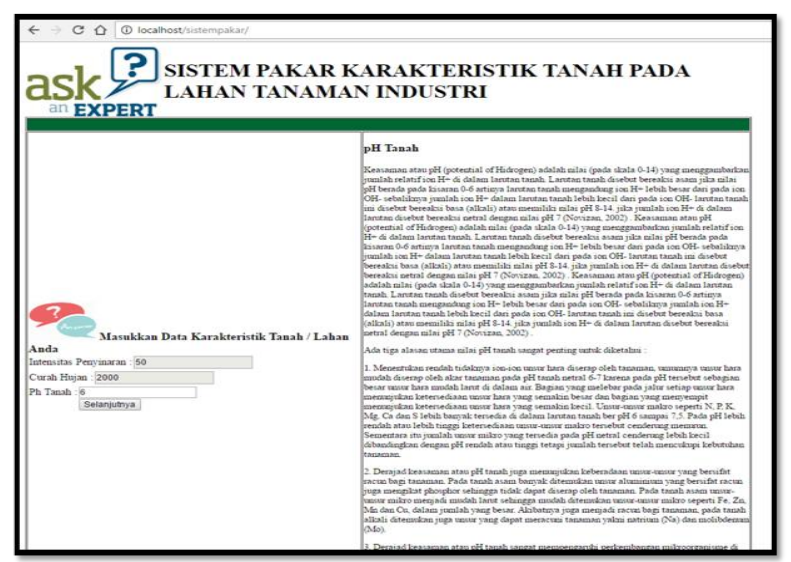

Gambar 6. User Interface Sistem Pakar Data pH Tanah 


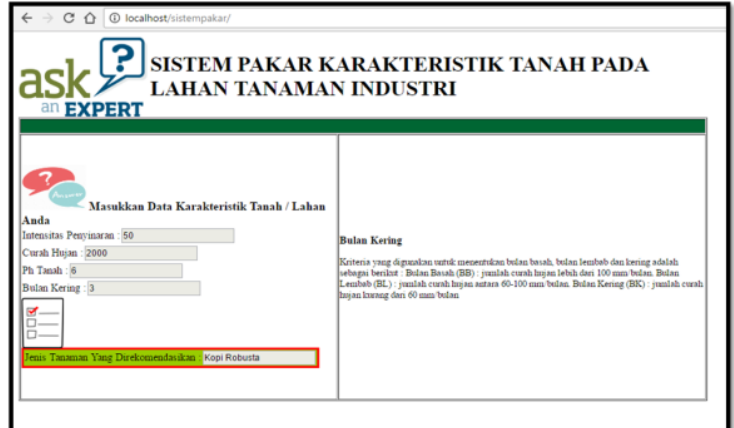

Gambar 7. User Interface Sistem Pakar Data Bulan Kering dan Hasil

\subsection{Uji Coba Data Sensor}

Sistem Pakar ini kemudian coba diuji menggunakan data lapangan langkah percobaannya ada persiapan sensor, pengambilan data menggunakan sensor dan pencocokan dengan pohon keputusan pada Gambar 2.

\subsubsection{Sensor Pengambilan Data}

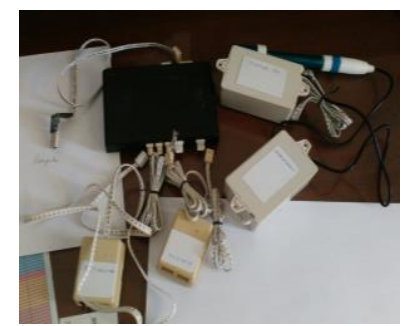

Gambar 8. Sensor - sensor yang digunakan

Pada Gambar 8 dapat dilihat Sensor-sensor yang digunakan antara lain :

1. Sensor Suhu

2. Sensor $\mathrm{pH}$

3. Sensor Kelembapan

4. Sensor Ketinggian

5. Sensor Kemiringan

Data Sensor tersimpan dalam data logger yang terhubung dengan komputer melalui usb. Beberapa sensor menunjukkan angka kurang valid karena keterbatasan alat pendukung.

3.2.2 Pengambilan Data Lapangan sebagai verifikasi Sistem Pakar Cengkeh

Data Pengambilan Data Lapangan untuk tanaman

\begin{tabular}{l}
\hline Pengambilan data tanggal $=03$ November 2016 \\
\hline Kondisi cuaca $=$ Hujan \\
\hline Tanaman $=$ cengkeh \\
\hline Lama pengambilan = 10 menit tiap data \\
\hline Lokasi = Desa Jambean Kec. Nongko Jajar \\
\hline
\end{tabular}

TABEL 2. PENGAMBILAN DATA CENGKEH

\begin{tabular}{|c|c|c|c|}
\hline \multicolumn{4}{|c|}{ cengkeh } \\
\hline waktu & kelembapan & suhu & $\mathrm{pH}$ \\
\hline 3:25:08 PM & 104.8983231 & 21.87602 & 6.8 \\
\hline $3: 25: 14$ PM & 105.0751572 & 21.82708 & 6.6 \\
\hline $3: 25: 20$ PM & 105.1812592 & 21.82708 & 6.4 \\
\hline $3: 25: 26 \mathrm{PM}$ & 105.2696762 & 21.82708 & 6.6 \\
\hline 3:25:32 PM & 105.4111404 & 21.87602 & 6.8 \\
\hline
\end{tabular}

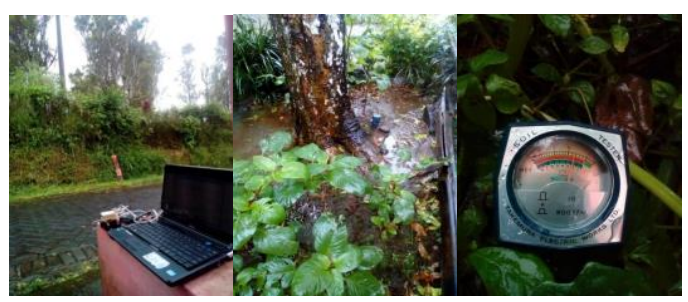

Gambar 1. Pengambilan data cengkeh

Dari hasil percobaan Tabel 2, pH cengkeh 6.4 s/d 6.8 pada tree $\mathrm{pH}$ cengkeh tidak dipersayaratkan hanya dipersyaratkan $<=2$ bulan kering $<=3$ dan intensitas penyinaran $>50$. Kopi Robusta

Data Pengambilan Data Lapangan untuk tanaman

\begin{tabular}{|c|c|c|c|}
\hline \multicolumn{4}{|c|}{ Pengambilan data tanggal $=03$ November 2016} \\
\hline \multicolumn{4}{|c|}{ Kondisi cuaca $=$ Hujan } \\
\hline \multicolumn{4}{|c|}{ Tanaman = Kopi Robusta } \\
\hline \multicolumn{4}{|c|}{ Lama pengambilan $=10$ menit tiap data } \\
\hline \multicolumn{4}{|c|}{ Lokasi = Desa Jambean Kec. Nongko Jajar } \\
\hline \multicolumn{4}{|c|}{ TABEL 3. PENGAMBILAN DATA KOPI ROBUSTA } \\
\hline \multicolumn{4}{|c|}{ kopi robusta } \\
\hline waktu & kelembapan & suhu & $\mathrm{pH}$ \\
\hline 4:50:13 PM & 111.2643661 & 23.78467 & 5.6 \\
\hline 4:50:19 PM & 111.317421 & 23.78467 & 5.4 \\
\hline 4:50:25 PM & 111.3527832 & 23.8336 & 5.6 \\
\hline 4:50:31 PM & 111.3704681 & 23.8336 & 5.6 \\
\hline 4:50:39 PM & 111.3881531 & 23.8336 & 5.4 \\
\hline
\end{tabular}

Dari hasil percobaan Tabel 3, pH Kopi Robusta 5.4 s/d 5.6 kopi robusta dipersyaratkan $>2$ bulan kering $<=3$ dan instensitas penyinaran $>50$ dan $\mathrm{pH}$ Tanah $<=6$

Data Pengambilan Data Lapangan untuk tanaman tebu

\begin{tabular}{l}
\hline Pengambilan data tanggal $=04$ November 2016 \\
\hline Kondisi cuaca $=$ cerah \\
\hline Tanaman $=$ tebu \\
\hline Lama pengambilan $=10$ menit tiap data \\
\hline Lokasi = Desa Karang Duren \\
\hline
\end{tabular}


TABEL 4. PENGAMBILAN DATA TEBU

\begin{tabular}{cccc}
\hline \multicolumn{3}{c}{ tebu } & \\
waktu & kelembapan & suhu & $\mathrm{pH}$ \\
\hline 11:09:01 AM & 73.5809021 & 47.66721 & 5.8 \\
\hline $11: 09: 07 \mathrm{AM}$ & 73.17417908 & 47.61827 & 5.4 \\
\hline $11: 09: 13 \mathrm{AM}$ & 72.51989746 & 47.91191 & 5.6 \\
\hline $11: 09: 19 \mathrm{AM}$ & 73.33333588 & 48.35236 & 5.4 \\
\hline
\end{tabular}

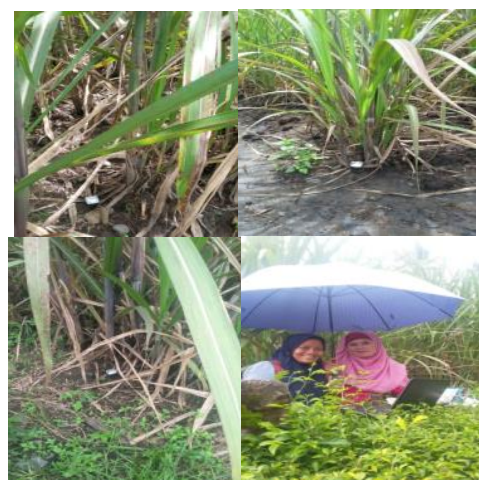

Gambar 11. Pengambilan data tebu

Dari hasil percobaan Tabel 4, pH Tebu 5.4 sd 5.8 hanya dipersyaratkan intensitas penyinaran $>50$ bulan kering $>3$

Data Pengambilan Data Lapangan untuk tanaman kakao

\begin{tabular}{l}
\hline Pengambilan data tanggal $=04$ November 2016 \\
\hline Kondisi cuaca $=$ cerah \\
\hline Tanaman $=$ kakao \\
\hline Lama pengambilan $=10$ menit tiap data \\
\hline Lokasi = Donomulyo \\
\hline
\end{tabular}

TABEL 5. PENGAMBILAN DATA KAKAO

\begin{tabular}{cccc}
\hline \multicolumn{4}{c}{ kakao } \\
\hline waktu & kelembapan & suhu & $\mathrm{pH}$ \\
\hline $2: 27: 38 \mathrm{PM}$ & 111.0698471 & 30.73409462 & 6.2 \\
\hline $2: 27: 44 \mathrm{PM}$ & 111.2290039 & 30.78303337 & 6.2 \\
\hline $2: 27: 50 \mathrm{PM}$ & 111.3881531 & 30.83197403 & 6.1 \\
\hline $2: 27: 56 \mathrm{PM}$ & 111.7771912 & 30.83197403 & 6.2 \\
\hline $2: 28: 02 \mathrm{PM}$ & 111.9717102 & 30.78303337 & 6.2 \\
\hline
\end{tabular}

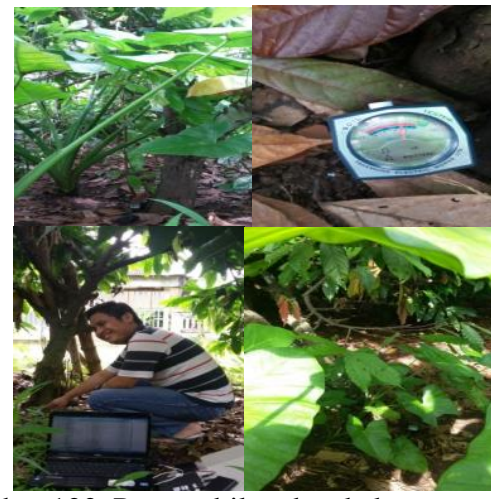

Gambar 122. Pengambilan data kakao

Dari hasil percobaan Tabel 5, kakao $\mathrm{pH}$ tanah $6.1 \mathrm{~s} / \mathrm{d}$ 6.2 ph tanah sesuai dengan tree $>=5.5$ dan intensitas penyinaran $<=20$

\section{KESIMPULAN}

Aplikasi Sistem Pakar telah berhasil disusun menggunakan javascript dan html dengan basis pengetahuan dan mesin inferensi menggunakan pohon keputusan metode C.45. Basis pengetahuan dan mesin inferensi telah diverifikasi menggunakan data uji lapangan dan hasilnya sesuai.

\section{DAFTAR PUSTAKA}

[1] Kementerian Perindustrian, 2015, Laporan Kinerja Kementerian Perindustrian

[2] Heru Junedi, 2015, Sistem Pakar Sambungan Diagnosa Gangguan Sambungan Telepon, Teknik Informatika, STMIK Raharja, Tangerang.

[3] Nina Sevani, 2009, Sistem Pakar Penentuan Kesesuaian Lahan Berdasarkan Faktor Penghambat Terbesar (Maximum Limitation Factor) Untuk Tanaman Pangan, Jurnal Informatika Vol. 10, No. 1, Mei 2009 $23-31$.

[4] Nita Merlina, M.Kom, 2012, Perancangan Sistem Pakar, Ghalia Indonesia, Bogor

[5] Rintiasti Aneke, Raflin Fuazi, 2018, Data Mining Untuk Menentukan Parameter Syarat Tumbuh Optimalbeberapa tanaman industry menggunakan metode C4.5, Jurnal Industri Hasil Perkebunan.

[6] Mochamad Try Yulyanto, 2014, Aplikasi Pohon dalam Sistem Pakar/ Expert System Klasifikasi Hewan dengan Bahasa Prolog, Program Studi Teknik Informatika, Teknik Elektro dan Informatika Institut Teknologi Bandung

[7] Rukmana, H. Rahmat dkk, "Untung Selangit dari Agribisnis Cengkeh", 2016, Lily Publisher, Yogyakarta

[8] Rukmana, H. Rahmat dkk, "Untung Selangit dari Agribisnis The”, 2015 , Lily Publisher, Yogyakarta

[9] Rukmana, H. Rahmat, "Untung Selangit dari Agribisnis Tebu”, 2015, Lily Publisher, Yogyakarta

[10] Sebastian Poeschl, Expert systems in special machinery: Increasing the productivity of processes in commissioning, 2017, Procedia CIRP 63, 545-550,

[11] Antesar M. Shabut, An intelligent mobile-enabled expert system for tuberculosis disease diagnosis in real time, 2018, Expert Systems With Applications 114 65-77

[12] Bibie Sara Salleh, 2015, Expert System on Selection of Mobility Management Strategies towards Implementing Active Transport, Procedia - Social and Behavioral Sciences 1952896 - 2904

[13] Gökhan Engin, 2014, Rule-based expert systems for supporting university students, 2014, Procedia Computer Science 31 ( 2014 ) 22 - 3 
[14] Nada S. Hussein , ESTJ: An Expert System for Tourism in Jordan, 2015, International Conference on Communication, Management and Information Technology, Procedia Computer Science 65821 - 826

[15] Fardhian Dwi Saputra, Sistem Pakar Menentukan Tingkat Kecocokan Lahan Untuk Tanaman Jati Menggunakan Metode Forward Chaining, 2016, JUITA ISSN:2086-9398 Vol. IV Nomor 1
[16] Meuthia Rachmaniah, Sistem Pakar Kesesuaian Lahan untuk Tanaman Nilam, 2018, , Jurnal Ilmu Komputer - Agri Informatika, http://journal.ipb.ac.id/index.php/jika 